\title{
Integrating the Belt and Road Initiative and Technical and Vocational Education and Training for Inclusive Growth and Development in Africa
}

\author{
Adekunle Osidipe \\ China Africa Education Cooperation Research Center, Institute of African Studies, Zhejiang Normal University, \\ 688, Yingbin Avenue, Jinhua, Zhejiang Province, China 321004
}

\begin{abstract}
Africa is plagued with persistent low competitiveness ranking at the lower rungs of the Global value Chain ladder in spite of the abundant resources the continent is endowed with. The demographic composition coupled with enormous resources of the continent are expected to be core drivers of comparative advantage in the quest for development, but these have not been properly harnessed. Technical and Vocational Education and Training (TVET) is believed to be pivotal to achieving targeted national or regional development goals, however, this critical aspect of education is being grossly neglected on the continent. TVET thrives through a coordinated synergy with economic environment in which it operates. A conducive environment for employment generating investments will strengthen the TVET systems and promote the development of key economic sectors to attract the requisite foreign development inputs. The Belt and Road Initiative (BRI) provides an avenue for flow of development inputs into Africa and fulfilling the BRI objectives in achieving inclusive growth and development in Africa requires effective capacity building beyond skills training of manpower. This paper examined the nexus between TVET and development, the opportunities available for BRI and TVET in key sectors of the economies in Africa. It emphasized that beyond the acquisition of skills, the continent should utilize the opportunities of BRI platform to promote inclusive growth and development by providing conducive environment for job creation through regional integration driven by infrastructure development, industrialization coupled with urbanization, and investment in research and development. It recommended that African countries should build and maintain strong and development driven TVET systems by taking cue from Chinese successful experience. The paper posited that the design of TVET system should dovetail with the national, regional and continental development goals to guaranty inclusive growth and development across the continent.
\end{abstract}

Keywords: Belt and Road Initiative, TVET, Development, Africa

DOI: $10.7176 / \mathrm{DCS} / 9-12-07$

Publication date: December $31^{\text {st }} 2019$

\section{Introduction}

The post-independence era in Africa ushered in a rapid expansion in education, however, as the population continued to grow coupled with the considerable success in the Education for All (EFA) programmes, significant pressure came on the post-basic education system, especially, at the secondary education level with many countries on the continent making inadequate provisions for effective accommodation of the increase at the post-basic education level. The continuous decline of public expenditure on education due on the one hand to misguided fiscal policies adopted on the recommendation of global lenders to reduce government expenditure on education, especially TVET, and on the other hand due to drastic crash in global commodity prices which has adverse effects on available funds to governments in African countries as they are predominantly primary resource-exporters has led to the poor state of education in being witnessed in the country. While much has been achieved on the continent in primary education with primary school enrolment put at $97.3 \%$, secondary school enrollment is just $42.8 \%$. At the tertiary level, a dismal $9.3 \%$ were enrolled in higher education as at 2017.

Table 1: Gross Enrolment by Level of Education in Sub-Saharan Africa

\begin{tabular}{|l|l|l|l|l|l|}
\hline & $\mathbf{2 0 1 3}$ & $\mathbf{2 0 1 4}$ & $\mathbf{2 0 1 5}$ & $\mathbf{2 0 1 6}$ & $\mathbf{2 0 1 7}$ \\
\hline Primary & $98.77 \%$ & $98.39 \%$ & $97.09 \%$ & $97.18 \%$ & $97.26 \%$ \\
\hline Secondary & $44.30 \%$ & $42.97 \%$ & $43.54 \%$ & $42.81 \%$ & $42.80 \%$ \\
\hline Tertiary & $8.85 \%$ & $8.98 \%$ & $9.11 \%$ & $9.28 \%$ & $9.31 \%$ \\
\hline
\end{tabular}

Source: UNESCO (http://data.uis.unesco.org/\#)

Enrolment in TVET on the continent paints a gloomier picture when compared with that in the secondary and tertiary education levels with less than $5 \%$ access to formal secondary school TVET in the region (AFDB \& OECD, 2008; UNESCO, 2019). The consistent neglect of TVET by various countries on the continent since the time of their independence significantly reflected in the scarcity of data on TVET in most of the countries. The most recent statistics on TVET enrolment in Africa was drawn from the global survey on access to formal TVET worldwide by the UNESCO Institute of Statistics in 2006. The data showed the enrolment of TVET in Africa as a percentage of secondary school enrolment. The survey grouped African countries in three groups. The first group encompasses 
10 countries with a proportion of TVET enrolment in general secondary education with 10 per cent or more. The second group has a proportion of TVET enrolment in general secondary education between 5 per cent and 9 per cent. The third group has enrolment proportion less than 5\% and there is another group of countries with no information available at the time of the survey.

Fundamental issues rooted in societal norms and prejudices, feeling of incapability, lack of encouragement and role models have been identified as responsible for the huge gap in male female enrolment ratio in TVET. In countries like Eritrea, Ethiopia, Malawi, Namibia, Niger and Uganda, female enrolment accounted for less than $15 \%$ in the total TVET enrolment and the share of TVET enrolment in overall secondary enrolment is less than $5 \%$. The quest for inclusive development on the continent will remain elusive without a change in the current trend in education on the continent; especially, considering the dismal enrolment in TVET on the continent when compared to other regions of the world.

Figure 1: TVET as a Percentage of Total Secondary Enrolment

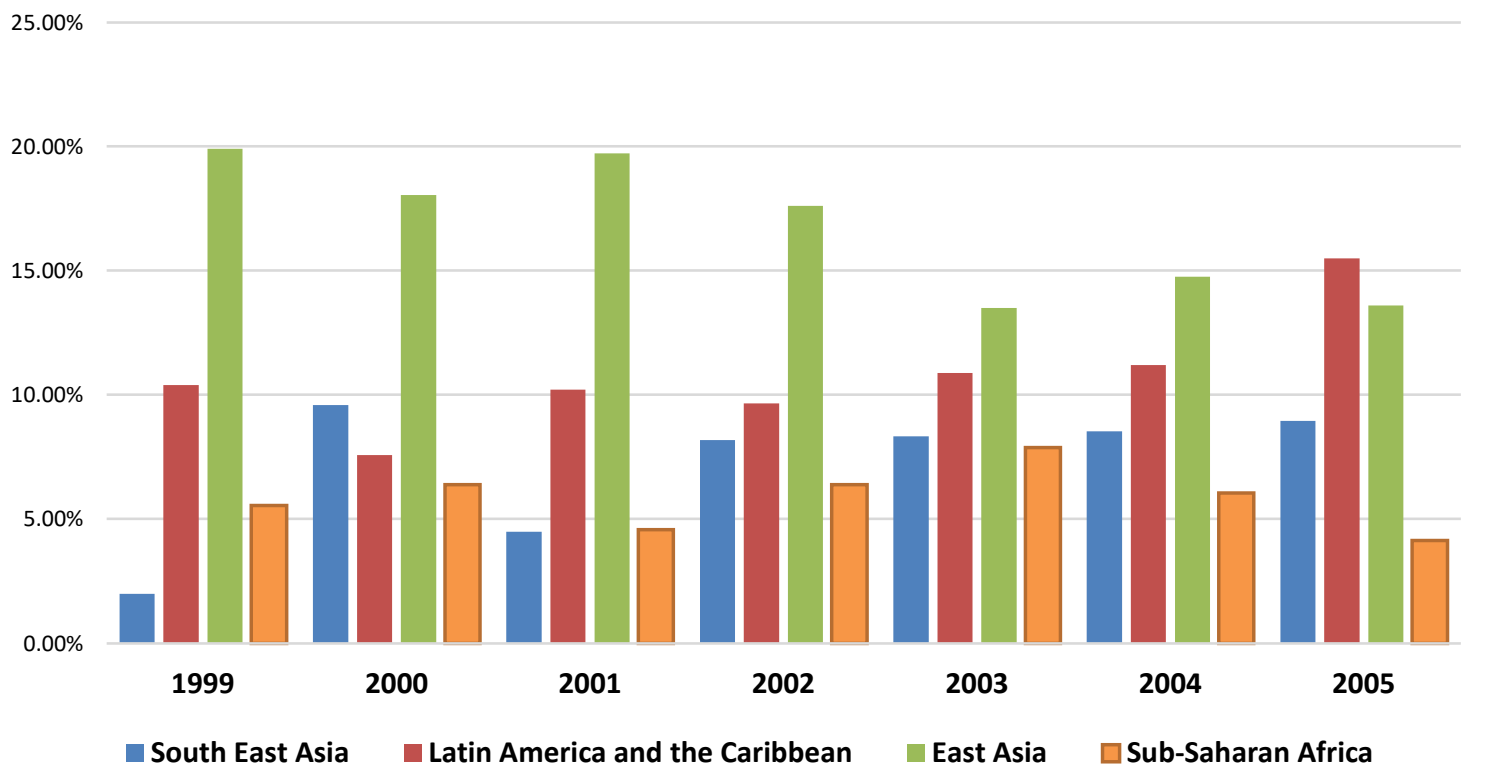

Source: Adapted from AFDB \& OECD (2008), from OECD Development Centre calculations based on UIS statistics http://dx.doi.org/10.1787/315817350525

The role of education in socio-economic growth and development cannot be over-emphasized, especially in an increasingly dynamic knowledge-based and information driven global economy. The continent critically needs investments that will drive employment. Attracting investors requires the availability of conducive environment for business growth and expansion which includes availability of infrastructure, knowledgeable and skilled technical manpower among others. The Belt and Road Initiative (BRI) provides a platform for African countries to create the enabling environment for employment-driven investments, thereby, triggering the repositioning of TVET to be more demand-driven and more attractive on the continent.

This paper intends to answer the following questions: what is the nexus between TVET and development in Africa? What are the fundamental constraints to TVET delivery in Africa? In what ways is the Belt and Road Initiative (BRI) relevant to development in Africa? And in what ways can African countries leverage on the Belt and Road Initiative (BRI) and TVET to achieve development? In the first part, the paper explores the meaning and fundamental challenges of TVET, the nexus between TVET and development in Africa, this is followed by exploring the prospects of the BRI in Africa's quest for development and the priority areas of integrating BRI and TVET for development as well as how this leveraging can be achieved.

Drawing from existing empirical data on TVET, BRI and development in Africa using the eclectic method, this paper posited that TVET's effectiveness in promoting employment, inclusive growth and development is dependent on the availability of employment generating ventures, which also require conducive environment in form of basic infrastructure, which are capital intensive and many African countries cannot afford to effectively finance due to limited finances. However, the BRI provides the opportunity to bolster infrastructure development and promote investment on the continent. It emphasized that to achieve the desired development through TVET, it must go beyond just provision of skills, a dynamism of economic context in which the skills learnt from TVET can be applied must be in place and BRI offers the platform for building this economic context. 


\section{TVET Defined}

In defining technical and vocational education, a major reference is the broad definition of technical and vocational education used in the UNESCO and ILO Recommendations on TVET for the Twenty-first Century:

"as a comprehensive term referring to those aspects of the educational process involving, in addition to general education, the study of technologies and related sciences, and the acquisition of practical skills, attitudes, understanding and knowledge relating to occupations in various sectors of economic and social life."

TVET refers, therefore, to a range of learning experiences that are relevant for the world of work and which may occur in a variety of learning contexts, including educational institutions and workplaces. TVET encompasses formal learning (provided in educational institutions or by public/private providers, as well as on the job) and nonformal learning (learning within or outside the workplace, usually outside educational institutions, such as traditional apprenticeship), aiming to ensure that all members of the community have access to the pathways of life-long learning. TVET includes both initial vocational training undertaken by young people prior to entering the labour market and continuing vocational training undertaken by adults whilst in work or during periods in which they are economically inactive. The Recommendations understand technical and vocational education as:

(a) an integral part of general education;

(b) a means of preparing for occupational fields and for effective participation in the world of work;

(c) an aspect of lifelong learning and a preparation for responsible citizenship;

(d) an instrument for promoting environmentally sound sustainable development;

(e) a method of facilitating poverty alleviation." (UNESCO \& ILO, 2002).

\subsection{Fundamental Challenges of TVET in Africa}

Several studies have identified diversities of challenges facing TVET in Africa ranging from paucity of funds to administrative bottlenecks and lack of policy coordination among others. However, for the purpose of this paper, the fundamental challenges of TVET in Africa are classified into two broad categories: external and domestic. The external challenges include influence of international donor agencies on TVET in Africa. During Postindependence era, most African countries in the 1960s and up till the late 1970s adopted TVET to meet expected skill requirements of industrialization and ease the problem of unemployment. However, concerns raised by the World Bank's rate of returns studies that showed higher returns on investment in general education than vocational education led to a drastic shift of interest to the funding of general basic education at the expense of funding of TVET. During the period between 1980s and 1990s, the World Bank's lending for TVET to the African region dropped sharply more than $40 \%$, compared to other parts of the world (Bennell \& Segerstrom, 1998). This affected the bank's financed education training projects and undermined much external support for TVET. From this point, the attractiveness of TVET began to wane as education provision in many African countries leaned mainly towards the general pathway and TVET considered as option for the low achievers.

The World Bank's decision adversely affected the development of TVET in most developing countries; especially, in Sub-Saharan Africa where commitment to TVET became dormant (Yamada, Shoko; Matsuda, 2007), considering the fact that most of the countries newly got independence and were unable to fully finance TVET provisions effectively without external lending. The Bank's decision effectively truncated the nascent growth of TVET in most African countries resulting in years of imbalance in education structure, underfunding of TVET, skills shortages, skills mismatch and massive unemployment. The policies of the international lending organizations, like the world bank, were primarily influenced by the conception that investment in TVET is investment in human capital as a means to supporting economic growth, where the underlying view of development in operation is an economic one in which "progress" is measured in relation to levels of economic growth and prosperity (Tikly, 2013).

The arguments of pro-economic researchers have been criticized by others who contended that the earlier failure of TVET in some developing countries should not be construed as a condition that TVET cannot succeed in other developing countries. According to Lewis (2009), and contrary to decades of policy edicts and supporting research, investment in formal vocational education does not always come to failure. Some scholars believe that the failure of TVET in developing countries has to do with the influence of the "Western paradigm" which held sway in developing countries despite their independence from the West. The effect of the Western paradigm, according to Keith Watson (1994) includes:

a. That too many governments have been swayed by the arguments put forward by multinational agencies, with the result that there has frequently been a disturbing disregard for indigenous opportunities and the reality of the local environment.

$b$. That the dependency culture, seen in terms of overseas training, course evaluations and assessment, the use of expatriate staff and Western equipment and machinery, has prevented the development of truly indigenous programmes, except where intermediate technology/self-help programmes have prevailed (Watson, 1994, p. 92).

At the domestic front, top on the list of major fundamental challenges of TVET are the disconnect of TVET 
strategies from the comprehensive employment policies, the inability of the employment market to expand enough to create jobs, TVET occupying marginal position in the school system compared to the general education, TVET not receiving enough attention from government and considered a last option for the low performing student in the general education stream, and low enrolment due to social stigma (AFDB \& OECD, 2008; Afeti \& Adubra, 2012; Atchoarena, D., 2001; Oketch, 2007). Others include supply-driven state-funded TVET delivery on the continent as against the demand-driven TVET.

The high costs of TVET provision has made it an unattractive venture for private providers when compared to the other education streams. Investment in TVET is inadequate compared to the development needs on the continent. However, state funded TVET is still required in order to have successful TVET delivery on the continent. Bennell and Segerstrom (1998) cited Korea and Taiwan as examples of countries that successfully relied upon state-funded specialized vocational education in secondary schools in their early period of industrialization period. In Korea, firms relied on government sponsored training, enterprise training tending to be unreliable. State funding of TVET is also the practice in China with very successful experience (Guo \& Lamb, 2010).

The success of China and some other Asian countries in TVET delivery demonstrates that TVET provides an indispensable support in government's efforts to enhance national competitiveness by producing a highly qualified and competitive workforce. Global competitiveness demands that African countries invest more in effective provisions of TVET as a human capital development strategy for driving Africa's competitiveness (WEF, AFDB, \& World Bank Group, 2017). Effective TVET is one that is strategically synchronized with the national development plans. A disconnect between the national development plan and education leads to the prevailing revolving "cycle of disadvantage" in countries on the continent today where people are inadvertently limited in choices.

\section{The Nexus Between TVET and Development in Africa}

The transformation of African economies into globally competitive economies with opportunities for decent work has been hinged on investment in human capital development through acquisition of relevant skills, knowledge and training (World Economic Forum, 2015, AFDB, 2011, 2015). Africa's population is young and vibrant and one of the fastest growing in the world. Economic growth has always been influenced by the human capital formation process through the expansion of primary schooling which leads to growth in secondary enrollment and investment in TVET which ultimately affects the quality and availability of human capital and economic growth (Rauner, 2005).

Globally, most countries recognized that essential sectors critical to national development like agriculture, construction, manufacturing, transportation, communications and commerce require a massive pool of skilled manpower, and that it is through TVET that such manpower can be obtained (Afeti, 2012). Also, various studies (Alam, 2015; Frow, Giguere, \& Hofer, 2009; Gough, 2010; Lewin, 1993) have shown that whether in developed or developing economies, investment in TVET is worthwhile. In recent years, global attention has shifted back to TVET as indispensable platform for provision of relevant knowledge, skills and competencies crucial for employment and sustainable livelihood (Maclean \& Wilson, 2009). Major reforms are being carried out in different countries globally consequent on the increasing recognition of the crucial role that higher technical skills play in enhancing competitiveness, social inclusion, decent employment and poverty reduction. The societal demand on TVET systems in terms of contribution to development has gone beyond the mere call for TVET to contribute to economic growth, employment and competitiveness, but for TVET to be a vehicle for social equity, inclusion and for sustainability of development (Marope, Chakroun, \& Holmes, 2015).

Human capital is critical to Africa's development, but the continent is not embracing the appropriate education suitable for the effective development of her human capital in tandem to her current development phase. TVET delivery is ought to go hand in hand with the development requirement of a society. Most African countries belong to the development stage that requires massive investment in TVET to meet the demand for growth and development. According to the Asian Development Bank (2008) there are four development stages each with corresponding type of TVET requirements as follows:

a. Factor-driven growth and low-cost manufacturing. This stage features extraction of natural resources. Low levels of vocational skill are required.

b. Transitional economies. Here reform of TVET is needed, especially regarding flexibility of program offerings, to reorient content with market-led dictates.

c. Investment Driven Growth Economies. Here there is accelerated, deepening demand for skills at the postsecondary technician level, with emphasis on mathematics, science and language.

d. Innovation driven growth countries. Here the focus is upon creativity and invention. The priority is upon science and engineering-based higher education, and on research and development (ADB, 2008, pp. 31-33). The typology allows that each stage of development requires a TVET approach that prepares it for the next stage. The first three stages of development (a-c) captures the current development stages of most of the African countries and the type of TVET required. 
The mobilization of science and technology in the context of TVET is vital for the much needed growth and development in developing countries of Africa, but the limited capacity to invest in their own science and technology sectors has led to serious "brain drains" in these countries (Yamada, Shoko; Matsuda, 2007). The effect of this reflects on the competitiveness of the continent at a time when the ability to train and retain human capital is considered a major "intangible" factor that contribute to a society's competitiveness (Kearns, Bowman, \& Garlick, 2008). African countries need to invest more in human capital development through TVET, not just for skills acquisition but as part of a broader social and economic development agenda that will ensure that national development plans do not operate in isolation from the human capital development plan. This becomes imperative as the convergence of globalization, technological development, and economic liberalization continue to drive governments all over the world to prioritize skills development as a key strategy for economic competitiveness and growth (World Bank, 2013).

The significance of TVET to development is rooted in the economic, social equity and sustainability rationales as contained in the Bonn Declaration that: "Since education is considered the key to effective development strategies, technical and vocational education and training (TVET) must be the master key that can alleviate poverty, promote peace, conserve the environment, improve the quality of life for all and help achieve sustainable development." (UNESCO-UNEVOC, 2004). Economically, TVET is the source of the requisite skills, knowledge and technology for productivity and competitiveness (World bank, 2005). A major constraint to economic development in Africa is the limitation on enterprise performance and efficiency due to skills gap and mismatch (World Economic Forum, 2008). The only hope of closing the skills gap and narrowing the mismatch between skills supply and demand is TVET (Marope et al., 2015; Mouzakitis, 2010).

However, TVET by itself does not automatically result in economic growth, employment or poverty eradication (AFDB \& OECD, 2008; Afeti \& Adubra, 2012). The impact of technical and vocational training on the "employability" of the labour force is not only a matter of the quality of skills acquired, but on the dynamism of the economic environment in the skills learnt can be applied. It has been observed that investment in skills development in rapidly growing economies tend to have high returns than in situations characterised by weak growth and poor governance (AFDB \& OECD, 2008). By enacting policies that engender job creation African countries will be able to reap significant benefits from the huge young population (WEF et al., 2017). Therefore, provision of TVET needs to transcend ordinary skills acquisition and include simultaneous implementation of reforms that engender the promotion and expansion of opportunities for business development and employment creation, with emphasis on skills for the sectors with the most promising employment prospects in order to have measurable impacts (AFDB 2008; Afeti). This is imperative as investment in knowledgeable, skilled and competent workforce has become a global competitiveness strategy for nations due to the significance of knowledgeable, skilled and competent workforce in how attractive a nation is to foreign investors and how soon technology transfer can be effected when required (Joshua A. Bello, 2005; Marope et al., 2015). The lack of this key element of attracting FDI could be seen in the dismal trend of FDI influx to Africa compared to other regions in the world as shown in the table below (UNCTAD, 2018, p. 20).

\section{Figure 2: Foreign Direct Investment (FDI) Inflows by Global regions (Billions of Dollars) 2016-2017}

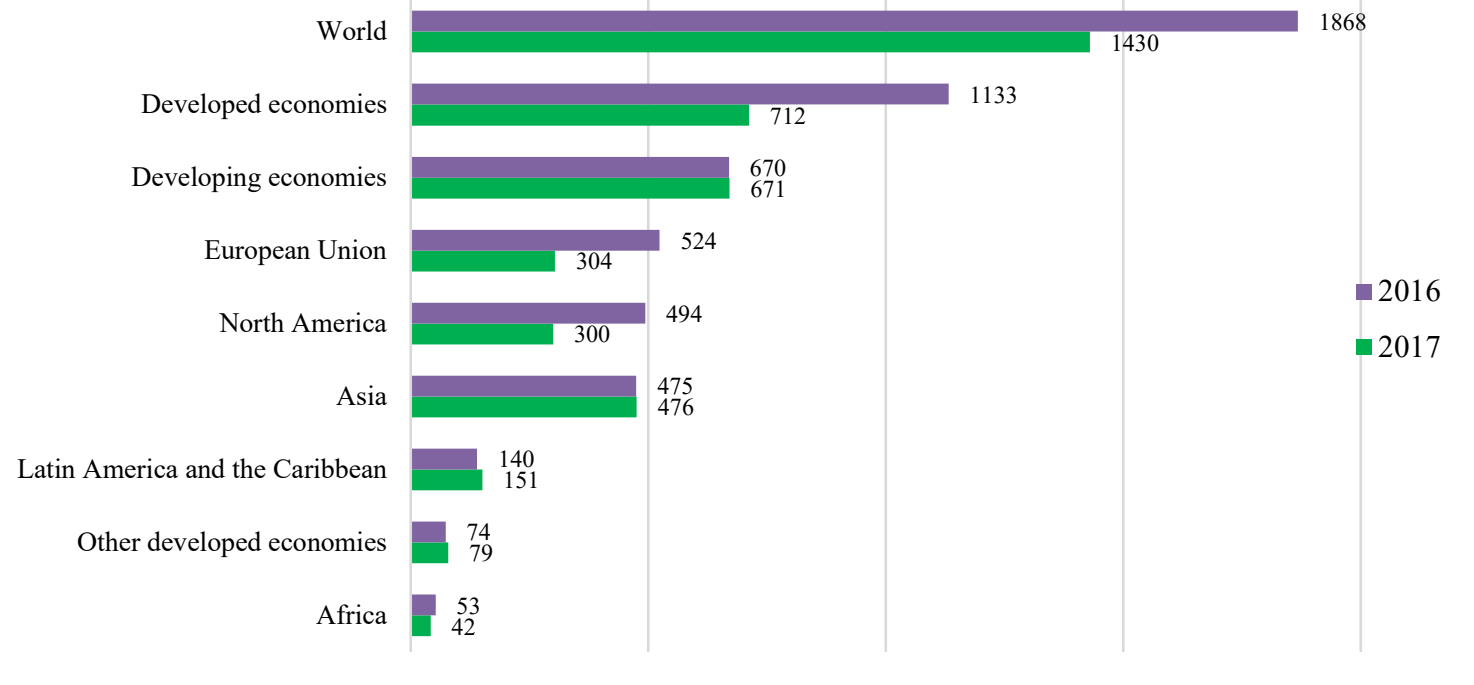

Source: UNCTAD, FDI/MNE database (www.unctad.org/fdistatistics) 
Studies have shown that developing countries that receive FDI perform better in terms of productivity than those without FDI (UNECA, AU, \& ADB, 2010). Globalization dynamics and advancement in technology make it imperative for a country's human capital to adapt to the changes in order to remain relevant and maintain considerable level of competitiveness. The quest of African countries to transform into industrialized economy requires significant inflow of FDI and technology transfer from the more technologically advanced countries. However, the manpower required for transfer of technology must be prepared ahead to be effective (Joshua A. Bello, 2005). TVET system provides the platform for equipping a country's manpower with the requisite knowledge, skills and competencies (Guo \& Lamb, 2010). How can Africa attract and retain critical FDI and technology transfer that comes with it? The answer is in how much the countries on the continent are ready to demonstrate their readiness by scaling up efforts to build and overhaul existing skills training systems in their respective domains and taking advantage of existing opportunities within and outside the continent, like the Belt and Road Initiative (BRI).

\section{The Prospects of the BRI in Africa's Inclusive Development}

The Belt and Road Initiative (BRI) promoted since 2013 by the Chinese President Xi Jinping, is an enigmatic new paradigm in global development partnership. Called the "One Belt and One Road" initiative at inception, the initiative since its inception has made significant progress in transforming from concept into concrete and practical global action for development. The Belt and Road Initiative links Asia, Africa and Europe, it encompasses more than $60 \%$ of the world population in over 68 countries and one-third of the world trade GDP. The initiative focuses on boosting economic development in countries on its route guided by five cooperation priorities of policy coordination, facilities connectivity, unimpeded trade, financial integration and people-to-people bond. The initiative, considered as overly ambitious by many, is a development drive conceived by the Chinese government under President Xi Jinping to boost trade and stimulate economic growth across Asia and beyond by massively building infrastructure that will connect several countries around the globe to China.

The countries and regions along the Belt and Road have vast diversity in levels of economic development, however, they have the potential to jointly benefit through socio-economic cooperation under the BRI with significant implications for global governance as well as to the advancement of sustainable development (UNDP China, CDB, \& SEPKU, 2017). A major intention of the BRI which also presents opportunities for African countries is the building of infrastructures across and within countries that are on the routes of BRI and enhance infrastructure connectivity framework. This opportunity if well harnessed is capable of helping African countries to overcome the constraints of infrastructure gap, weak regional integration and inability to take advantage of economies of scale that have beleaguered the continent's vision for inclusive development.

Though the BRI has been criticized as overly ambitious global trade expansionist programme of the Chinese, and some critics believe the BRI pays too much attention to trade and infrastructure, but studies have established that trade is a key factor in promoting economic growth and poverty reduction as it promotes exchange of goods and services among participating countries as well as encourages the allocation of resources based on the perceived comparative advantages of participating countries (Baldwin, 2003). Also, trade enhances economic integration with the outside world and enables participating countries to fully exploit their abundant means of production, compels local businesses to improve their technologies as a result of competition from imports, encourages technological innovation through the diffusion of new technologies from more advanced countries among others. More significantly and most relevant to the African countries is that international economic integration through opportunities offered by BRI creates the inevitable platform for foreign direct investment (FDI) which is an important channel through which technology transfer across national boundaries can take place (Baldwin, 2003; Schiff \& Winters, 2003; UNECA et al., 2010).

Though the impact of Belt and Road Initiative's likely ricocheting effect across the continent of Africa still appears to be unclear when compared to that of other regions on its route, yet it is believed that Africa has the opportunity to take advantage of the strategy to drive the much needed development in infrastructure which is lifeblood of industrialization and economic development on the continent. From 2015 when the agreement to build infrastructure to link countries in Africa was signed with the African Union, China has been involved in several large-scale infrastructure projects across the continent. From support to Egypt's USD45 billion new administrative capital, to the USD 12billion coastline railway to connect Benin, Nigeria and Cameroon, the USD3.3billion transshipment port in Algeria and the USD4 billion Djibouti Port, in which the Chinese company China Merchants Group is the second largest shareholder, to Addis Ababa railway. There is the USD3.8billion Mombasa-Nairobi railway line and the revival of single longest railway in Sub-Saharan Africa, the Tanzania-Zambia railway as well as the repair of the railway line from Dakar (Senegal) to Bamako (Mali) at the cost of USD 2.73billion (China Daily, 2016; WWF, 2016). The list keeps increasing.

In the power sector, China through the BRI has engaged in the construction of power projects to improve power supply on the continent, including the "North Africa Power Corridor" comprising Egypt, Algeria, Tunisia, Morocco and Sudan, the "east Coast Power Corridor" comprising Kenya, Tanzania, Mozambique, South Africa, 
Ethiopia, Uganda, Zambia and Zimbabwe as well as a host of other African countries. China is also engaged in development cooperation with African countries through the BRI for industrialization on the continent (WWF, 2016).

With the agreement signed in the 2015 FOCAC meeting, china and African countries pledged to work together to promote industrial partnering and building industrial capacity (FOCAC, 2015a). Since then, under the agreement, china undertakes to pool resources to build demonstration zones, and combine the construction of large infrastructure projects such as railway, roads and ports with the building of industrial parks and Special Economic Zones (SEZs), so as to build industrial belts along the routes and achieve sound interaction between large-scale infrastructure projects and industrial development. Unimpeded trade is one of the cardinal objectives of the BRI which is expected to be achieved through the creation of free trade zones, which can not only boost bilateral trade, but also promote international industrial cooperation. The new free trade zones in African countries are planned to promote trade and reduce the trade imbalance between China and African countries (FOCAC, 2015b, 2019; WWF, 2016).

Inclusive growth and development in Africa will be triggered through regional development that will have a ripple effect across the continent. A major challenge to realizing regional integration on the continent is the lack of infrastructure and a conducive environment for investments in employment generation ventures. Inclusive regional development in Africa should target key sectors comparative advantage in each region that will promote rapid integration and enhance the establishment of regional learning communities, partnerships and social capital. This paper identified three areas that could be leveraged on to integrate the BRI provisions into building skills development and employment oriented TVET delivery in Africa at regional levels including manufacturing, infrastructure development and agriculture.

\subsection{Manufacturing and Industrialization}

A strong manufacturing sector is broadly understood as an essential path to economic growth and development. Industrial development in Africa will enhance the creation of new opportunities, increased jobs openings and contribute to poverty alleviation (AFDB, 2019). Manufacturing plays critical role in in promoting growth even in other sectors especially in transition economies moving from low to middle income status (like most of the developing countries in Africa) because it drives greater scope of productivity boost as workers shift from the primary agricultural sector (Howlett \& Mukherjee, 2018; Signé \& Johnson, 2018). The state of the manufacturing sector value added in Africa, though low when compared to other regions of the world, provides a platform of opportunity for enterprises through the BRI to invest more in the sector that has the potential to drive other sectors for overall productivity.

Table 2: Manufacturing Value Added (\$billions) in Global Regions (2017)

\begin{tabular}{|lc|}
\hline Region & Manufacturing Value added (\$billions) \\
\hline Sub-Saharan Africa & 165.65 \\
\hline East Asia \& Pacific & $6,484.48$ \\
\hline South Asia & 514.28 \\
\hline Europe and Central Asia & $3,304.69$ \\
\hline Latin America \& Caribbean & 748.84 \\
\hline North America & $2,338.23$ \\
\hline
\end{tabular}

Source: From World Development Indicators, World Bank (2017)

Strengthening of the manufacturing sector is a key strategy to significantly create jobs and reduce poverty on the continent as well as increase the productivity and competitiveness of the countries on the continent (UNECA et al., 2010). Manufacturing sectors thrive on the availability of skilled human capital, therefore, creating conducive environment for investment in manufacturing in Africa will trigger demands for relevant workforce which will also have spill-over effect in terms of strengthening of the existing TVET institutions, reforms in the design of TVET programmes to meet the needs of enterprises. Thus, making TVET demand-driven instead of the ineffective supply-driven systems which makes employment difficult for graduates. With a demand driven TVET programme, TVET becomes more attractive to students who know that they will not be stranded on completion of their studies.

Africa has great manufacturing potential with positive projections for business-to-business spending in manufacturing on the continent, yet the continent is still a marginal player in the global trade with a meagre share of just $2.4 \%$, but global trade is a major player in the economic affairs of African countries with import and export services accounting for more than 50\% of their GDP signaling an overdependence on imports with no corresponding balance in export (Schmieg, 2016; Signé, 2017). In leveraging on BRI and TVET delivery for development, African countries should pay more attention to the development of manufacturing industry coupled with robust trading network within the continent as against the current trend of low intra-continent trading compared to what obtains in other regions (AFDB, OECD, \& UNDP, 2017). 


\subsection{Infrastructure Development}

Critical to Africa's growth and development is the building of infrastructure network. Studies have shown that that better quantity and quality of infrastructure can directly raise the productivity of human and physical capital and hence growth and the poor state of infrastructure in many parts of Africa reduced national economic growth by $2 \%$ points every year, reducing productivity by about $40 \%$ (Ianchovichina, Estache, Foucart, Garsous, \& Yepes, 2013). The implication of this is that Africa will continue to have low global productivity level in spite of its enormous mineral and other natural resources if the state of infrastructure on the continent remains the same.

Debates are still ongoing on whether infrastructure has a real developmental effect. Some are of the view that investment in advanced infrastructure facilities can be costly for developing countries with scarce resources as it drains the financing that could have been allocated to other emerging developmental plans. Low planning and implementation capacities (Dang \& Sui Pheng, 2015), and inadequate human capital (Hanushek, 2013) among other contributing factors can lead to developing economies abandoning investment in other projects with higher socio-economic outcomes if they merely prioritize investment in infrastructure projects. However, existing empirical findings on the impact of infrastructure on development in developing countries find positive nexus between infrastructure and economic development (Straub \& Terada-Hagiwara, 2010) just as it enhances total productivity factor (Escribano, Guasch, \& Pena, 2010). Infrastructure also enables local industry to compete effectively locally and have a positive edge over foreign competitors, and it constitutes the backbone of economic development in most developing countries and affects rural development through improved agricultural productivity, increased rural nonfarm employment and rural-urban migration (Escribano et al., 2010; Sahoo \& Dash, 2008).

For African countries, the BRI provides the platform to leverage on infrastructure construction projects in meeting the employment needs. The infrastructure construction industry has the potential not only to deliver infrastructure but also provide employment opportunities to the unemployed, underemployed and those working in vulnerable conditions (ILO, 2018). Studies have shown that in countries like Brazil, Chile, Costa Rica, Mexico, Turkey, and several other countries in the Southeast Asian region, investment in quality infrastructure is a significant component of improved investment climate which results in productivity employment, real wages, exporting activities, and foreign direct investment (FDI) inflows (Escribano, Guasch, Orte, \& Pena, 2008; Escribano et al., 2010).

The state of infrastructure in Africa represents both challenge and prospects. In a cross-country comparison study on the impact of infrastructure quality on firm's productivity in Africa, the quality of electricity provision is a major problem for more than $50 \%$ of firms in more than half of the 26 countries studied (Escribano et al., 2010). When compared to other regions of the world, the huge infrastructure gap in Africa presents prospects for investment in the sector.

Table 3 Infrastructure: Electricity, Internet, Broadband and Air transport in Selected Global Regional Groupings (2017)

\begin{tabular}{|l|l|l|l|l|}
\hline Region & $\begin{array}{c}\text { Access to electricity } \\
\text { (\% of population) }\end{array}$ & $\begin{array}{c}\text { Internet Usage } \\
(\% \text { of population) })\end{array}$ & $\begin{array}{l}\text { Fixed broadband } \\
\text { subscriptions }\end{array}$ & Air transport, \\
\hline Sub-Saharan Africa & 44.6 & 22.1 & $5,082,126$ & 719,553 \\
\hline East Asia \& Pacific & 97.8 & 55.1 & $507,943,257$ & $9,886,329$ \\
\hline South Asia & 89.9 & 30.2 & $28,792,548$ & $1,298,761$ \\
\hline European Union & 100 & 80.6 & $175,686,617$ & $6,173,910$ \\
\hline North America & 100 & 77.0 & $123,784,613$ & $11,082,914$ \\
\hline
\end{tabular}

Source: Based on World Development Indicators: Africa Infrastructure Country Diagnostic (2019)

Access to physical infrastructure drives GDP, growth and social returns, but requires the availability of adequate skills and strong institutions to experience the growth payoff. The more competitive the host environment in terms of skills and strong institutions, the higher the payoff (Ianchovichina et al., 2013; Ndulu, Niekerk, \& Reinikka, 2005). Therefore, the development of infrastructure requires a critical mass of investment in human resources for engagement in the process of infrastructure building as well as ensure a smooth process of technology transfer which always accompany such projects. This will be achieved through the establishment of key specialized TVET institutions to provide relevant skills and trainings and research.

\subsection{Agriculture}

Through the BRI platform, African countries can take cue from China's successful experience in TVET for agricultural and rural development. The Chinese experience provides a model in effective synergy of various sectors of the economy in phased development programme. Many studies have linked China's gradual and consistent rise to global power within three decades to the unique provision of school based TVET (Chen, 2016; Keating, Medrich, Volkoff, \& Perry, 2002; Wu \& Ye, 2009; Zhaoli, 2013). Within three decades, the country has transformed into a global manufacturing base, and experienced structural transformations in the economy as the share of agriculture output and employment significantly declined in favour of industry and services. Between 
1990 and 2015, the percentage of the population employed by agriculture declined significantly from $60.1 \%$ to $28.3 \%$. On the other hand, the population employed in the manufacturing (secondary sector) and services (tertiary industry) sectors of the economy increased to $29.3 \%$ and $42.4 \%$ respectively.

Table 4: GDP Contribution and Employment Population Distribution by Industry

\begin{tabular}{|l|l|l|l|l|l|l|}
\hline \multirow{2}{*}{} & \multicolumn{2}{|c|}{ Agriculture } & \multicolumn{2}{c|}{$\begin{array}{c}\text { Manufacturing/ } \\
\text { Construction }\end{array}$} & \multicolumn{2}{c|}{ Services/Tourism } \\
\cline { 2 - 7 } & $\begin{array}{c}\text { Output } \\
(\%)\end{array}$ & $\begin{array}{c}\text { Employment } \\
\text { proportion (\%) }\end{array}$ & $\begin{array}{c}\text { Output } \\
(\%)\end{array}$ & $\begin{array}{c}\text { Employment } \\
\text { proportion (\%) }\end{array}$ & $\begin{array}{c}\text { Output } \\
(\%)\end{array}$ & $\begin{array}{c}\text { Employment } \\
\text { proportion (\%) }\end{array}$ \\
\hline 1990 & 27.1 & 60.1 & 41.3 & 21.4 & 31.6 & 18.5 \\
\hline 1995 & 19.9 & 52.2 & 47.2 & 23.0 & 32.9 & 24.8 \\
\hline 2000 & 15.1 & 50.0 & 45.9 & 22.5 & 39.0 & 27.5 \\
\hline 2004 & 13.4 & 46.9 & 46.2 & 22.5 & 40.4 & 30.6 \\
\hline 2006 & 11.7 & 42.6 & 48.9 & 25.2 & 39.4 & 32.2 \\
\hline 2008 & 11.31 & 39.6 & 48.62 & 27.2 & 40.07 & 33.2 \\
\hline 2010 & 10.1 & 36.7 & 46.7 & 28.7 & 43.2 & 34.6 \\
\hline 2012 & 10.1 & 33.6 & 45.3 & 30.3 & 44.6 & 36.1 \\
\hline 2014 & 9.2 & 29.5 & 42.7 & 29.9 & 48.1 & 40.6 \\
\hline 2015 & 9.0 & 28.3 & 40.5 & 29.3 & 50.5 & 42.4 \\
\hline
\end{tabular}

Source: (National Bureau of Statistics China, 2016b)

The gradual drop in the employment proportion in primary industry and steady rise in the employment proportion in the secondary (manufacturing) and tertiary (services) industries signals significant increment in the number of skilled manpower available for employment in the latter two sectors. Furthermore, due to the continued growth in socio-economic development in China, the living conditions of the general population continues to rise with corresponding increase in the number of residents living in cities (not due to rural -urban migration, but due to the transformation of hitherto rural areas into modern cities). This can be seen in the table below showing the percentage of urbanization in China between 1978 and 2014:

Table 5: Percentage of Urbanization Level in China

\begin{tabular}{|l|l|l|l|l|l|l|l|l|l|}
\hline $\mathbf{1 9 7 8}$ & $\mathbf{1 9 9 0}$ & $\mathbf{1 9 9 5}$ & $\mathbf{2 0 0 0}$ & $\mathbf{2 0 0 4}$ & $\mathbf{2 0 0 6}$ & $\mathbf{2 0 0 8}$ & $\mathbf{2 0 1 0}$ & $\mathbf{2 0 1 2}$ & $\mathbf{2 0 1 4}$ \\
\hline $\mathbf{1 7 . 9 0}$ & 26.4 & 29.04 & 36.22 & 41.76 & 43.90 & 44.90 & 50.00 & 53.00 & 55.00 \\
\hline
\end{tabular}

Source: (National Bureau of Statistics China, 2016a)

The common challenge facing the countries in Africa is poverty reduction and to reduce poverty, hunger must be eradicated through strategic investment in sustainable agricultural practices and processing. There is huge demand for agricultural mechanization on the continent as many of the countries still practice subsistence farming system with very poor productivity. For instance, agricultural practice in the Central African region relies primarily on human manual power for land preparation on about $85 \%$ of the cultivated land (Mrema, Kienzle, \& Mpagalile, 2018; NEPAD, 2013; World Bank Group, 2017). Depleting arable land and labour force in the face of growing global demands for sophisticated certifications for agricultural products make it mandatory for technological transformation in agriculture that will enable farmers to increase their yields within the limited resources available to them and still meet the global requirements.

Such transformation requires well trained and skilled personnel which makes specialized agricultural TVET an indispensable option. Agricultural focused TVET will enhance the ability of the continent's bourgeoning youth population to successfully transition to productive technology-based sectors (AFDB, 2018). Agricultural TVET programmes will provide participants with the skills for agricultural production, processing and trade. African countries must not only embrace agriculture, but equally embrace agricultural production processes that preserve and add value to the agricultural produce

\section{How to Leverage on BRI for Improved TVET Delivery in Africa}

The BRI is guided by five cooperation priorities of policy coordination, facilities connectivity, unimpeded trade, financial integration and people-to-people bond. Under the people-to-people bond is the education agenda with four key programmes for implementation which can be effectively taken advantage of by African countries in building a development oriented TVET system across the continent to promote inclusive growth and development on the continent taking cue from China's successful experience in this area. The four areas are:

i). Silk Road Two-Way Student Exchange Enhancement Program. The programme is expected to train skilled technical personnel in the countries along the routes by providing scholarships for study abroad in China and for Chinese students to study abroad in the countries on the BRI route. This is in addition to existing scholarship programmes being offered to students and scholars from Africa to study in China. This arrangement will enable African countries train more technical manpower that will be directly relevant to various development projects on 
the continent, especially in areas of infrastructure development, continental trade expansion, and agricultural development.

ii). Silk Road Co-Operation in Running Educational Institutions and Programs Enhancement Program. Under this programme, Chinese universities as well as top TVET institutions, based on their strong disciplinary fields, can engage in international cooperation with counterparts on the BRI route to choose the right entry points for cooperation, conduct reliable feasibility surveys, and put in place systems and models for education and training, management and operations, service to the locality, and public relations with the community and the host countries. The international cooperation agreements are expected to be jointly set up and implemented in cooperation with industries and business entities to achieve industry-education integration under the active engagement of the governments of the host countries. The partnership will set up TVET institutions and training centers that will be actively engaged in development projects in the host countries, thereby enhancing employment training for young people

iii). Silk Road Teacher Training Enhancement Program. The Silk Road teacher training programs offers the platform for resource sharing and exchange among the teaching and management personnel of educational institutions along the BRI route through exchanges, visits and refresher courses and study tours for teaching and management personnel. It is expected to promote learning and development as educational institutions along the BRI route engage in exchange of quality teaching equipment, courseware, and full-package teaching solutions with the aim of achieving equitable distribution of educational resources and balanced development of education among the BRI countries.

iv). Silk Road Joint Education and Training Enhancement Program. Under this programme, universities will be engaging in academic exchanges and visits, carry out joint education and training programs needed to meet the urgent development demands of the countries on the BRI route in various disciplines to facilitate the sharing of educational resources among university alliances and between universities with bilateral relations.

\section{Conclusion}

With the abundant natural and human resources abounding in Africa, embracing TVET is an inevitable option in Africa's quest for development to bring the army of young population out of unemployment, poverty and poverty triggered insecurity. Transition from resource-dependent economy to a more productive economy requires that aside from dedicated policy on skills training systems, complementary policies to stimulate job creation must be simultaneously promoted. These can include policies supporting investment in infrastructure, sound economic policy, favorable investment climate, and the promotion of policies favorable to trade and competitiveness (WEF et al., 2017). The BRI offers opportunity to address infrastructure gap in Africa as the initiative seeks to massively promote infrastructure development in countries on its route, thereby offering African countries the opportunity to create conducive environment for investment in employment creation ventures through the improvement of infrastructure on the continent. The socio-economic development of countries and regions in Africa need to be strategically linked to the nurturing and management of the human resources in the various regions.

Also, provisions of training need to be designed based on the development need of the immediate environment. Connecting development projects to trainings in TVET could be very beneficial to enhancing the validity and reliability of the projects, because they are flexible, they can be designed with the unique characteristic of being integrational and made to fit the existing demands of specific region(s) depending on the existing realities in each places. Key priority areas of manufacturing, infrastructure and agriculture have the potential to help Africa establish demand-driven and effective skills training systems that will curb the trend of cycle of disadvantage by removing limitations which hinder the young population from fully contributing their quota to the development of their immediate societies as responsible citizens.

TVET is not just about skills acquisition because skills acquisition alone cannot bring about development. Development requires a synergy of knowledge, skills acquisition with the economic environment in which the knowledge and skills acquired can be applied. African countries must create conducive environment for job creation to increase the demand for skills, by taking advantage of the opportunities in the BRI to overcome the challenge of weak infrastructure system on the continent inhibiting the expansion of opportunities for business development and employment that will eventually absorb the graduates of TVET institutions (ILO, 2015a). The BRI offers the opportunity for integration of TVET to the development goals of the continent as it offers infrastructure construction, investment and education cooperation that will enhance human capital development.

\section{References}

ADB. (2008). Education and Skills: Strategies for Accelerated Development in Asia and the Pacific.

AFDB. (2018). African Economic Outlook 2018. Abidjan.

AFDB. (2019). African Economic Outlook 2019. Abidjan.

AFDB, \& OECD. (2008). African Economic Outlook 2008.

AFDB, OECD, \& UNDP. (2017). African Economic Outlook 2017. Abidjan. https://doi.org/10.1787/aeo-2017-en 
Afeti, G. (2012). Technical and vocational education and training for industrialization. Mode of Access: Http://Www. Arrforum. Org/Index. $\quad$ Php, 1-18. $\quad$ Retrieved from http://www.arrforum.org/publications/documents/Afeti Technical Education.pdf

Afeti, G., \& Adubra, A. L. (2012). Skilling Africa: The Paradigm Shift to Technical and Vocational Skills Development, 1-12.

Alam, N. (2015). the Role of Technical Vocational Education and Training in Human Development: Pakistan As a Reference Point. European Scientific Journal, 11(10), 35-50.

Atchoarena, D., D. (2001). Revisiting Technical and Vocational Education in sub-Saharan Africa: an Update on Trends, Innovations and Challenges. Paris.

Baldwin, R. (2003). Openness and growth: What's the empirical relationship? NBER Working Paper (NBER No. 9578).

Bennell, P., \& Segerstrom, J. (1998). Vocational education and training in developing countries: has the World Bank got it right? International Journal of Educational Development, 18(4), 271-287. https://doi.org/10.1016/S0738-0593(98)00021-2

Chen, M. (2016). 中国职业教育改革与发展实践. ( (中国改革开放与发展实践从书/刘洪武), Ed.) (第1版). 沈阳: 辽宁教育出版社.

China Daily. (2016). CMG plans network of ports, terminals | Business. Retrieved September 16, 2019, from https://www.chinadailyasia.com/business/2016-06/02/content 15443229.html

Dang, G., \& Sui Pheng, L. (2015). Infrastructure Investments in Developing Economies. Infrastructure Investments in Developing Economies. https://doi.org/10.1007/978-981-287-248-7

Escribano, A., Guasch, J. L., Orte, M. De, \& Pena, J. (2008). Investment Climate Assessment Based on Demean Olley and Pakes Decompositions : Methodology and Application to Turkey's Investment Climate Survey 1.

Escribano, A., Guasch, J. L., \& Pena, J. (2010). Assessing the Impact of Infrastructure Quality on Firm Productivity in Africa Cross-Country Comparisons Based on Investment Climate Surveys from 1999 to 2005. Policy Research Working Papers 5191.

FOCAC. (2015a). Declaration of the Johannesburg Summit of the Forum on China-Africa Cooperation. Retrieved September 17, 2019, from https://www.focac.org/eng/zywx_1/zywj/t1327960.htm

FOCAC. (2015b). The Forum on China-Africa Cooperation Johannesburg Action Plan(2016-2018). Retrieved September 16, 2019, from https://www.focac.org/eng/zywx_1/zywj/t1327961.htm

FOCAC. (2019). Chinese aid helps put African nations on track. Retrieved September 14, 2019, from https://www.focac.org/eng/zfgx_4/jmhz/t1696172.htm

Frow, F., Giguere, S., \& Hofer, A. (2009). Designing Local Skills Strategies. Leed.

Gough, S. (2010). Technical and Vocational Education and Training An Investment-Based Approach. NEW YORK: Continuum International Publishing Group.

Guo, Z., \& Lamb, S. (2010). International Comparisons of China's Technical and Vocational Education and Training System (Vol. 12). Dordrecht: Springer Netherlands. https://doi.org/10.1007/978-90-481-8743-0

Hanushek, E. A. (2013). Economic growth in developing countries: The role of human capital. Economics of Education Review, 37, 204-212. https://doi.org/10.1016/j.econedurev.2013.04.005

Howlett, M., \& Mukherjee, I. (2018). Routledge Handbook.

Ianchovichina, E., Estache, A., Foucart, R., Garsous, G., \& Yepes, T. (2013). Job Creation through Infrastructure Investment in the Middle East and North Africa. World Development, 45, $209-222$. https://doi.org/10.1016/j.worlddev.2012.11.014

ILO. (2018). Creating jobs through public investment. Retrieved from http://www.ilo.org/wcmsp5/groups/public/--ed_emp/---emp_policy/---invest/documents/publication/wcms_619821.pdf

Joshua A. Bello. (2005). Fiscal Policy and the Growth of Foreign Direct Investment in Sub-Saharan Africa (Selected Countries: Ghana, Kenya, Nigeria, and South Africa). Retrieved from https://etd.auburn.edu/bitstream/handle/10415/229/BELLO_JOSHUA_7.pdf;sequence=1

Kearns, P., Bowman, K., \& Garlick, S. (2008). The double helix of vocational education and training and regional development. Retrieved from http://www.ncver.edu.au/research/proj/nr6014.pdf

Keating, J., Medrich, E., Volkoff, V., \& Perry, J. (2002). Comparative Study of Vocational Education and Training Systems: national Vocational and Training Systems Across Three Regions Under Pressure of Chnage. NCVER Ltd. Retrieved from https://www.ncver.edu.au/_data/assets/file/0025/9754/comparative-study-ofvet-systems-863.pdf

Lewin, K. (1993). Investing in technical and vocational education: A review of the evidence. Vocational Aspect of Education, 45(3), 217-227. https://doi.org/10.1080/0305787930450303

Lewis, T. (2009). International Journal of Educational Development Towards reclaiming the high ground in the discourse on vocationalism in developing countries, 29, 558-564. https://doi.org/10.1016/j.ijedudev.2009.01.002

Maclean, R., \& Wilson, D. (Eds.). (2009). International Handbook of Education for the Changing World of Work. 
Dordrecht: Springer Netherlands. https://doi.org/10.1007/978-1-4020-5281-1

Marope, P. T. M., Chakroun, B., \& Holmes, K. . (2015). Unleashing the Potential Transforming Technical and Vocational Education and Training.

Mouzakitis, G. S. (2010). The role of vocational education and training curricula in economic development. Procedia - Social and Behavioral Sciences, 2(2), 3914-3920. https://doi.org/10.1016/j.sbspro.2010.03.616

Mrema, G. C., Kienzle, J., \& Mpagalile, J. (2018). Current status and Future Prospects of Agricultural Mechanization in Sub-Saharan Africa (SSA). AGRICULTURAL MECHANIZATION IN ASIA, AFRICA AND LATIN AMERICA, 49(2), 13-30.

National Bureau of Statistics China. (2016a). China's Urbanization Process 中国城镇化进程. Retrieved October 8, 2017, from http://data.stats.gov.cn/swf.htm?m=turnto\&id=432

National Bureau of Statistics China. (2016b). China Statistical Yearbook 2016. Retrieved September 18, 2018, from http://www.stats.gov.cn/tjsj/ndsj/2016/indexeh.htm

Ndulu, B., Niekerk, L. K., \& Reinikka, R. (2005). Infrastructure, Regional Integration and Growth in Sub-Saharan Africa. Africa in the World Economy, (December), 101-121.

NEPAD. (2013). Agriculture in Africa Transformation and Outlook. Retrieved from www.nepad.org

Oketch, M. O. (2007). To vocationalise or not to vocationalise? Perspectives on current trends and issues in technical and vocational education and training (TVET) in Africa. International Journal of Educational Development, 27(2), 220-234. https://doi.org/10.1016/j.ijedudev.2006.07.004

Rauner, F. (2005). Vocationalisation of Secondary Education Revisited. (R. Maclean, D. N. Wilson, J. Lauglo, \& R. Maclean, Eds.) (Vol. 1). Berlin/Heidelberg: Springer-Verlag. https://doi.org/10.1007/1-4020-3034-7

Sahoo, P., \& Dash, R. K. (2008). Economic Growth in South Asia: The Role of Infrastructure. Series No. E/288/2008.

Schiff, M., \& Winters, L. A. (2003). Regional Integration and Development. IBRD/World Bank.

Schmieg, E. (2016). Africa's Position in Global Trade - Free Trade Agreements, WTO and Regional Integration, $1-12$.

Signé, L. (2017). 3 Things to Know about Africa's Industrialization and the Continental Free Trade Area. Retrieved May 24, 2019, from https://www.brookings.edu/blog/africa-in-focus/2017/11/22/3-things-toknow-about-africas-industrialization-and-the-continental-free-trade-area/

Signé, L., \& Johnson, C. (2018). The potential of manufacturing and industrialization in Africa: Trends, opportunities, and strategies. Africa Growth Initiative at Brookings. Retrieved from www.brookings.edu/global

Straub, S., \& Terada-Hagiwara, A. (2010). Infrastructure and Growth in Developing Asia. Asian Development Bank Economics Working Paper. Manila.

Tikly, L. (2013). Reconceptualizing TVET and Development: a Human Capability and Social Justice Approach. Revisiting Global Trends in TVET: Reflections on Theory and Practice, 3-39. Retrieved from http://www.unevoc.unesco.org/go.php?q=Revisiting global trends in TVET Reflections on theory and practice

UNCTAD. (2018). World Investment Report 2018 Investment and New Industrial Policies. https://doi.org/10.18356/a1e0466b-en

UNDP China, CDB, \& SEPKU. (2017). The Economic Development along the Belt and Road.

UNECA, AU, \& ADB. (2010). Assessing Regional Integration in Africa IV Enhancing Intra-African Trade. https://doi.org/e-ISBN-13: 978-92-1-055278-3

UNESCO-UNEVOC. (2004). Bonn Declaration on Learning for Work, Citizenship and Sustainability. In UNESCO International Meeting of Technical and Vocational Education and Training Experts. Bonn, $\begin{array}{lllllll}\text { Germany, } & 25 & \text { to } & 28 & \text { October } & 2004 & \text { Retrieved }\end{array}$ http://www.unevoc.unesco.org/fileadmin/user_upload/pubs/SD_BonnDeclaration_e.pdf

UNESCO. (2019). Technical and Vocational Education and Training at UNESCO's Office in Dakar | United Nations Educational, Scientific and Cultural Organization. Retrieved July 8, 2019, from http://www.unesco.org/new/en/dakar/education/technical-and-vocational-education-and-training/

UNESCO, \& ILO. (2002). Technical and Vocational Education and Training for the Twenty-first Century. United Nations Educational. Scientific and Cultural Organization (UNESCO) and International Labour Organization (ILO). Retrieved from http://unesdoc.unesco.org/images/0012/001260/126050e.pdf

Watson, K. (1994). Technical and Vocational Education in Developing Countries: Western paradigms and comparative methodology. Comparative Education, 30(2), 85-97. https://doi.org/10.1080/0305006940300202

WEF, AFDB, \& World Bank Group. (2017). The Africa Competitiveness Report 2017 - Addressing Africa's Demographic Dividend. Geneva. Retrieved from http:/www.weforum.org/en/initiatives/gcp/Global Competitiveness Report/index.htm

World bank. (2005). World Development Report 2006: Equity and Development. Washington, DC. 
World Bank. (2013). The World Bank Annual Report 2013. Annual Report 2013. https://doi.org/10.1596/978-08213-9937-8

World Bank Group. (2017). Africa's Pulse An analysis of issues shaping Africa's economic future. Africa's Pulse (Vol. 15). Retrieved from http://documents.worldbank.org/curated/en/348741492463112162/pdf/114375REVISED-4-18-PMWB-AfricasPulse-Sping2017-vol15-ENGLISH-FINAL-web.pdf

World Economic Forum. (2008). The Global Competitiveness Report 2008-2009. Geneva.

World Economic Forum. (2015). The Global Competitiveness Report The Global Competitiveness Report (Vol. 5). https://doi.org/92-95044-35-5

Wu, X., \& Ye, Y. (2009). Technical and Vocational Education in China. (C. Socol, Ed.) (1st ed.). Hangzhou: Zhejiang University Press.

WWF. (2016). China's Belt and Road Initiative \& its Implications for Africa. Nairobi. Retrieved from http://assets.wwfke.panda.org/downloads/china_s_belt_and_road_initiative_and_its_implications_for_afric a.pdf

Yamada, Shoko; Matsuda, N. (2007). Vocational and Industrial Human Resource Development through TVET in Africa : Changing Assistance Environments and Human Resource Demands. Development. Tokyo.

Zhaoli, C. (2013). 职业教育集团化办学试点项目实施方案. (蔡钊利, Ed.) (1st ed.). 西安: 西安电子科技大学 出版社. 